【カテゴリーI】

日本建築学会計画系論文集 第81巻 第723号, 1123-1131, 2016年5月

J. Archit. Plann., AIJ, Vol. 81 No. 723, 1123-1131, May, 2016 DOI http://doi.org/10.3130/aija.81.1123

\title{
大都市既成市街地および中山間地域における 余暇および交流活動に関する研究 \\ A COMPARTIVE STUDY ON THE RECREATION, ASSOCIATION LIFE, IN URBAN DISTRICTS OF LARGE CITIES \\ AND IN THE INTERMEDIATE AND MOUNTAINOUS AREA
}

\author{
齋藤雪彦*, 椎野 亜紀夫** \\ Yukihiko SAITO and Akio SHIINO
}

This paper aim to clarify the situation of the isolation in urban districts of large city and a district of intermediate and mountainous area among residents in the view point of recreational life. It makes clear as follows.

1) About from $40 \%$ to $60 \%$ residents do not join each local association activities while about $10 \%$ resident do in intermediate and mountainious area .2) About from $20 \%$ to $35 \%$ resident do not join almost all of local association activities and about $10 \%$ resident do not join almost all of association activities. 3) Such a isolation group of residents are seen in every ages which is not seen in a specific age.

4) Isolation and individualization are expected to be seen widely in the metropolitan urban area comparing to provincial urban area.

Keyuords: Recreational life, I solation, large city, intermediate and mountainious area ,Non-Communication Society 余㗇生活，孤立，大都市，中山間地域，無縁社会

\section{1. はじめに}

国立社会保障・人口問題研究所の将来推計によると、一人暮らし の高齢者は全国で 2010 年は 498 万人だが、2035 年には 762 万人 に増加し、東京都では 2010 年の 64 万 7 千人から、2035 年に 104 万 3 千人になる注1)。同時に大都市では、コミュニケーションのあ り方が変化し、孤立死が社会的課題となっている。近年では、貧困 等により、世帯ごと孤立死する事例も散見される注2)。こうした状 沉下で、都市計画学・農村計画学では、空き家や高齢者の生活行為、 居場所等の課題が研究されてきたが、福祉学の領域に留まらず、「孤 立」という居住のあり方も新たな研究課題と捉えられる。

「孤立」とは、一般的に「ある個人が、誰ともつき合いがなく、 社会から切り離された状態」を指すが、本研究では、その背景であ るコミュニケーション（つきあい）を総合的に捉えるため、これを 「狭義の孤立」とし、「ある個人が、限定的に特定の者（家族や一部 の友人）とはつき合うが、地域社会等社会集団から切り離された状 態」を「広義の孤立」とする注3)。大都市には「広義の孤立」状態 にある住民は珍しくはないが、家族、友人との疎遠に加え、失業、 病気、家族の介護等により、容易に「狭義の孤立」に陥るため、こ
れは潜在的な社会問題である。

「広義の孤立」について、年功序列に代わる社会的連帯の根拠が 不在なことが要因として挙げられる。欧米では個人の自立を前提と した個人の良心に社会的連帯の基礎がある。一方、わが国では、コ ミュニティ・集団での関係性にその基礎があり、「よそ者」に対する 冷淡さが、コミュニティや集団の形骸化により、「孤立」という形で 析出されてきたと言える注4)。同時に、消費社会システムが高度化 し(例えば、インターネット、宅配、24 時間営業のコンビニなどの サービス)、「生活の個人化」が進行したこと注5)、労働環境の変化 （成果主義、非正規雇用の一般化、企業間競争の激化）により、組 織や社会への帰属意識が低下し、労働によるストレスの増加で地域 社会におけるコミュニケーションを行う精神的、物理的余裕のない 者が増加したことなども要因として挙げられる注6)。

前編注7) では、小都市中心市街地および近郊地域を対象地とした が、本編では、大都市地域、中山間地域を対象地として、前編で得 られた、地域内、地域外における人間関係に関わる余暇活動、交流 活動に関する指標を用い、大都市既成市街地と中山間地域との比較 を行うが、総合考察では前編で得られた小都市中心市街地および近 
郊地域との比較も行う。

また、本編では、前編と同様に、地域社会における近所つきあい や自治会活動を含めて余暇活動とする。つまり、個人的な楽しみと しての余㗇活動と地域内外の義務的なつきあいを併せて余㗇活動と する。また、同時に、余暇活動のうち、人とのつきあいに関わる活 動を交流活動とした。

本研究の着想は、都市近郊農村地域において、生産や生活の共同 性が衰退しただけでなく、住民の一部で「広義の孤立」が散見され ること、これを前提とする計画論が求められていると考えたことで ある。本編の目的は、中山間地域、大都市地域（首都圈大都市既成 市街地、地方圈大都市既成市街地）における余暇、交流活動の活動 種類毎の地域差を定量的に明らかにし、地域社会等社会集団との関 係を持たない（「広義の孤立」、以下地域内外での非交流）層の広が りを見て、同時に前編で得られた都市近郊農村地域の状況を相対化 することである。

既往研究のレビューについて、まず、農村社会学（環境社会学） の分野では、農村社会の封建性、コミュニティの限界性に関して指 摘する研究は見られたが 11) 12)、現代的課題である地域内外での非 交流層に関する研究はほとんど見られない。

また、社会福祉学・保健福祉学の分野では、高齢者や障害者の親 族間ネットワークにおける孤立など、「狭義の孤立」に関する研究が 散見されたが 13）14）、個人と地域のつながりを総合的に分析するよ うな「広義の孤立」に関する実証的な研究はほとんど見られない。

計画学では、地域交流活動や地域組織に関して多数の研究蓄積が ある。特定の施設、活動、階層に着目し、地域における組織活動・ 個人のつながりを明らかにした研究は多い。特に、地域活動への参 加の消極性を取り上げる研究では、その解消に関わる考察も展開さ れ、本編と問題意識を共有する 15) 16)。さらに、地域組織や個人の つながりを体系的に見て、その活動実態やあり方、コミュニティの 活性化に資する条件を整理する視点も見られる 17) 18)。こうした地 域組織や個人のつながりを体系的に見る研究は本研究の指標の検討 の際に参考となる基礎的研究と位置づけられる。ソーシャル・キャ ピタル（社会関係資本）という概念を用い、地域社会における交流 活動を定量的に捉え、これをコミュニティの活性度の指標とし、政 策的な援用を企図する研究が多く見られるが、個人の具体的活動を 個別に測定する研究はほとんど見られない19）20)。

藍沢らは、地域組織の活動内容やつきあいを類型化し、その活動 の範域、地域差、参加者属性を分析し、政策的に地域社会活動の活 性化手法を提案している 21）22）。いずれも、地域内外での非交流層 を指摘するものではないが、地域組織と個人のつながりを総合的に 扱い、本編と共通する視点を持つ。

最後に、近年のインターネット利用についても、地域内外の非交 流を促進させるとの指摘と同時に、対面しなくてもつきあいが存在 するという意味で、余暇・交流活動に大きな影響を与えている ${ }^{23}$ 。 本編では現実の交流にのみ着目し、インターネットでのつきあいを 含めた総合的なつきあいの考察は今後の課題としたい。

\section{2. 研究の方法}

\section{$2-1$. 対象地域}

研究の対象地域は、首都圏大都市既成市街地として松戸市 $\mathrm{M}$ 地区
のうち、 $1-4$ 丁目（以下 $\mathrm{M}$ 地区）、地方圈大都市既成市街地とし て札幌市 K 地区、中山間地域として静岡市 U 地区を選定した。 $\mathrm{M}$ 地区、 $\mathrm{K}$ 地区は筆者らが所属する研究機関の近隣地域である。つま り、こうしたプライバシーに関わる調査を行う際に、研究機関への 理解が深い地域であれば、比較的高い回収率が見込まれると考えた ためである。また、集合住宅の多い地区でなく、戸建て住宅が中心 の既成市街地とした。これは、自治会に所属する住民も少なくなく、 地域一の帰属意識がある程度見込まれ、農村地域との相似性と回収 率を期待したためである。静岡市 U 地区は、大学との交流を軸とす る地域づくりを展開しており、地域の実態を把握したいとの意識を 持ち、調查協力と高い回収率が見込まれたためである。調查対象地 の概要を表 1 に示す。地域組織について、3 地域とも複数の自治会 による組織があるが (自治会連合会等)、地域組織の活動内容は異な る注8)。こうした活動の質的差異による回答のバイアスがあること を踏まえ、また定量分析による限界にも留意し考察を進める。

松戸市 $\mathrm{M}$ 地区、札幌市 K 地区ともに、高度経済成長期に市街化 が進んだ戸建て住宅地である。市街地の規模は異なるが、松戸市 $\mathrm{M}$ 地区は、東京圈から連坦する市街地の外延部にあり、札幌市 K 地区 も札幌市中心部から連坦する市街地の外延部にあり、両地区とも郊 外住宅地と捉えることができる。世帯数について M 地区は 1795 世 帯、K 地区は 1415 世帯となる。

$\mathrm{U}$ 地区は、静岡市中心市街地から、車で 1 時間半の時間距離にあ る中山間地域である。南アルプスの山麓に位置し、地形が急峻なた め、栽培作目は茶などに限られる。温泉があり、旅館など観光関連 産業と建設業が主たる産業であり、世帯数は 172 世帯である（調査 時点)。

\section{$2-2$. 研究の方法}

まず、調查対象両地域において、アンケート調查を行った（表 1 )。 一般的に女性よりも男性の方が社交的でなく、地域で孤立しや寸い と言われており注 9)、本編では成人男性を調查対象者とした。アン ケート調査は、悉皆調査として、各世帯にアンケート票を配布し、 郵送による回収とした。ただし、U 地区では、自治会連合会の協力 が得られたため、自治会連合会による配布を行い、回収は公民館に

\section{表 1 調査対象地および調査の概要}

\begin{tabular}{|c|c|c|c|}
\hline 地区名 & 松戸市M地区 & 札幌市K地区 & 静岡市U地区 \\
\hline 地区の立地 & 首都圏大都市既成市街地 & 地方圏大都市既成市街地 & 中山間地域 \\
\hline 配布·回収 & 戸別配布·郵送回収 & 同左 & 自治会配布·公民館にて回収 \\
\hline 実施時期 & 2011年秋 & 2011年夏 & 2011年夏 \\
\hline 調査対象者 & 成人男性(各) & 帯に1通配布、2人以上の & 合はコピーを依頼） \\
\hline 世帯数 & 1795 & 1415 & 172 \\
\hline 有効回答数 & 343 & 397 & 103 \\
\hline 有効回答率 & $19.1 \%$ & $28.0 \%$ & $59.9 \%$ \\
\hline 質問項目 & d & & つきあい、近所つき \\
\hline
\end{tabular}

表 2 回答者の基本属性（\%)

\begin{tabular}{|c|c|c|c|}
\hline 職業。 & M地区 & K地区 & U地区 \\
\hline 無職 & 34.5 & 40.6 & 18.6 \\
\hline 農業 & 0.3 & 0.5 & 25.5 \\
\hline 自営業 & 16.7 & 8.4 & 30.4 \\
\hline パート等 & 6.7 & 5.4 & 2.9 \\
\hline 会社員 & 41.8 & 45.2 & 22.5 \\
\hline 年齢 & M地区 & K地区 & U地区 \\
\hline 20 代以下 & 4.1 & 2.3 & 2.9 \\
\hline 60 代以上 & 57.1 & 59 & 51.5 \\
\hline 居住年数 & M地区 & K地区 & U地区 \\
\hline 30年以上もしくは先祖代々居住 & 48 & 30.6 & 91.2 \\
\hline 家族構成 & M地区 & K地区 & U地区 \\
\hline 単身居住 & 10.2 & $\overline{6} \cdot \overline{6}$ & $8 . \overline{7}$ \\
\hline 1世代居住 & 32.7 & 41 & 25.2 \\
\hline
\end{tabular}




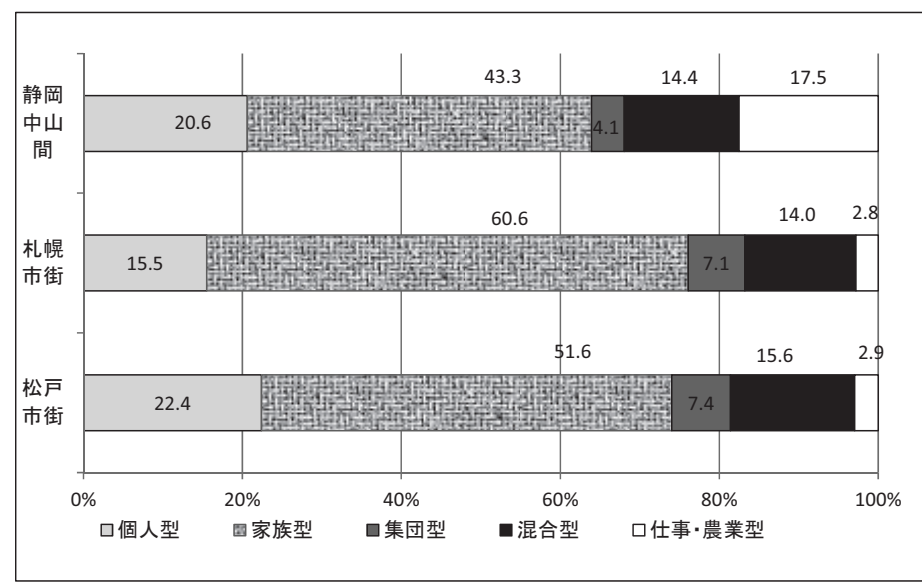

図 1 余暇活動の主たる相手

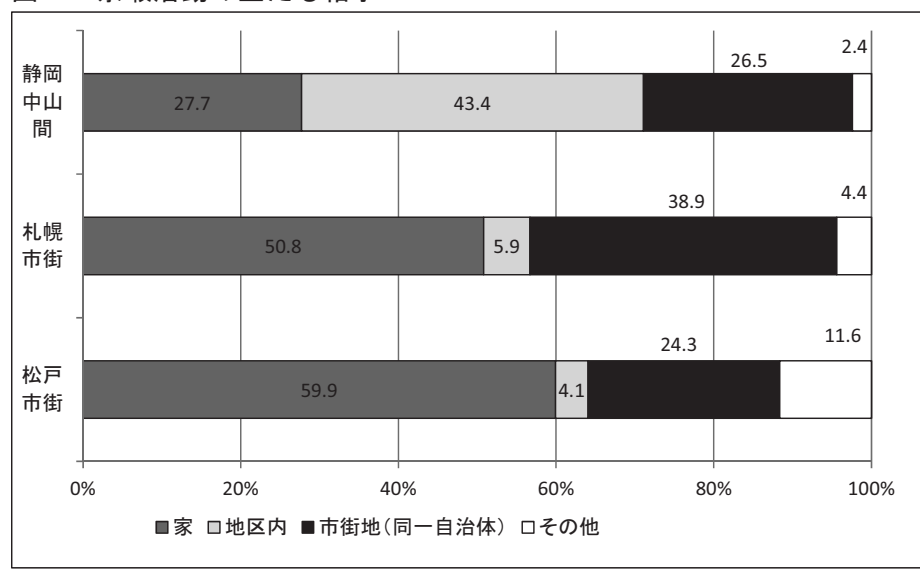

図 2 余暇活動の主たる場所

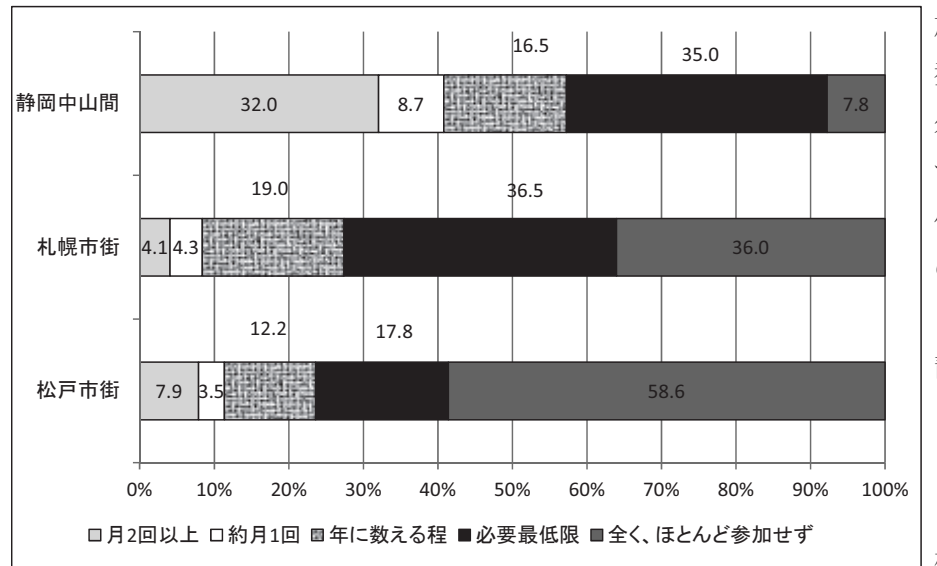

図 3 地域組織活動の参加頻度

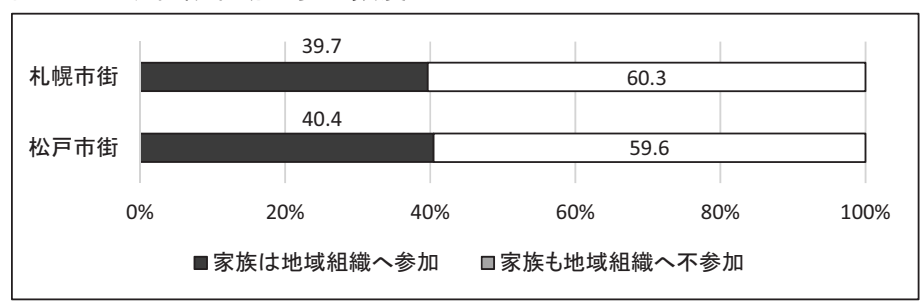

図 4 地域組織不参加者の同居家族の状況

回収箱を設置し回収した。また、該当する世帯員が複数の場合は、 コピーを指示したが実際にこうした事例はなく、配布、回収方法の 相違を含め、方法論としての課題が残った。 $\mathrm{M} 、 \mathrm{~K} 、 \mathrm{U}$ 地区それぞ
れ、有効回答が 343、397、103 票であり、有効回答率は 19.1\%、 $28 \% 、 59.9 \%$ である。なお、回答者の基本属性を表 2 に示す。なお、 図表および本文中では松戸市 M 地区を「松戸市街」もしくは首都圈 大都市地域、札幌市 $\mathrm{K}$ 地区を「札幌市街」もしくは地方圈大都市地 域、静岡市 U 地区を「静岡中山間」もしくは中山間地域と表記する。

地域における人間関係に関わる交流活動ついては、地域組織への 参加、地域における個人的つきあい（地域のつきあいと表記）、近所 付き合いから、また地域外における人間関係に関わる交流活動につ いては、地域外組織への参加と地域外における個人的つきあい（地

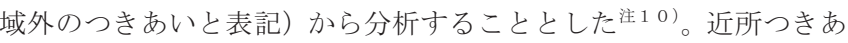
いについては、「挨拶もしない」、挨拶をする程度」、「立ち話をする 程度」、「裾分けをする程度」、「家を訪問したり、立ち入った話を する」のいずれかを選択してもらい、「挨拶もしない」と「挨拶をす る程度」と回答したサンプルを地域での近所つきあいに消極的な層 として分析を進めた。加えて、別居家族、親戚とのつきあいや、同 居家族の地域内外におけるつきあい、相談相手の有無なども分析の 対象とした。

従って、i） 3 章では、余暇活動の内容、相手、頻度、場所から、 その特徴を見て、ii) 4 章で、家族や親せき以外の者との交流活動に 着目し、地域内および地域外の交流活動の頻度から、その特徵を見 て、iii) 5 章で、知見をまとめ、今後の課題を提示した。

\section{3. 余暇活動の実態 \\ 1 ）余暇パターン}

生活全般について「主に誰と余暇を過ごすか」の傾向を「余暇パ ターン」注1 1 1) とし、（1)主に「1 人」で過ごす「個人型」（2)主に「家 族と」、あるいは「1 人で」、「家族と」の組み合わせで過ごす「家族 型」、(3)主に「家族以外の人」と過ごす「集団型」、(4) (1)から (3)以 外で「家族以外の人」と「1人で」、「家族と」の組み合わせで過ご す「混合型」、(5)仕事や農業が忙しくてあまり余暇がない、あるいは 仕事や農業が余暇のようなものだと認識している「仕事・農業型」 の 5 種のパターンを設定し回答を得た（図 1 ）。まず、「個人型」と 「家族型」の合計の割合を見ると松戸市街 $74.0 \%$ 、札幌市街 $76.1 \%$ 、 静岡中山間 $63.9 \%$ である。大都市地域で約 7 割 5 分、中山間地域で も約 6 割 5 分の回答者が余暇を個人あるいは家族で過ごすとしてい る。

一方、主に、友人や組織で日常的に余暇を過ごす「集団型」は、 松戸市街 $7.4 \%$ 、札幌市街 $7.1 \%$ 、静岡中山間 $4.1 \%$ で、いずれの地 域も 1 割以下である。つまり、中山間地域であっても、大都市と同 様に余睱を友人や仲間と過ごすよりも、個人や家族で過ごすことが 一般的になっていることが確認される注 12$)$ 。理由を聞くと「家族サ 一ビスを優先したい」、「個人が気楽、自分の時間が大事」が併せて 約 8-9 割で、回答者の置かれた環境ではなく、余暇に対する考え方 による (データ割愛)。つまり、中山間地域のような伝統的共同性が 残存すると考えられる地域であっても、友人との交流や組織の活動 を日常的に行う者は少なくなっている注 13 )。

\section{2）主に余暇活動を行う場所}

「主に余暇活動を行う場所」について、「家」と回答する割合は、 松戸市街 59.9\%、札幌市街 50.8\%、静岡中山間 27.7\%、で、大都 市地域の 5-6 割に上り、中山間地域でも約 3 割であり、余暇を自宅 


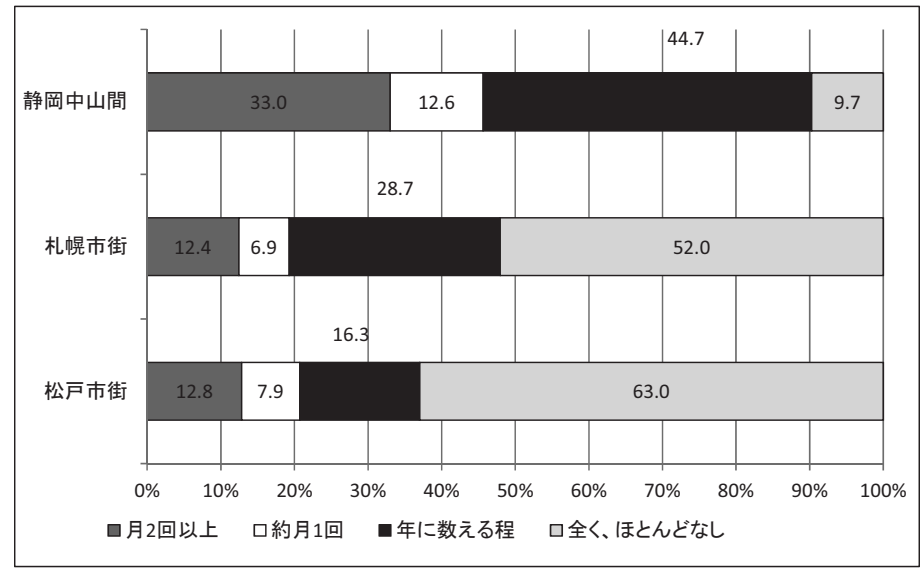

図 5 地域つきあいの実施頻度

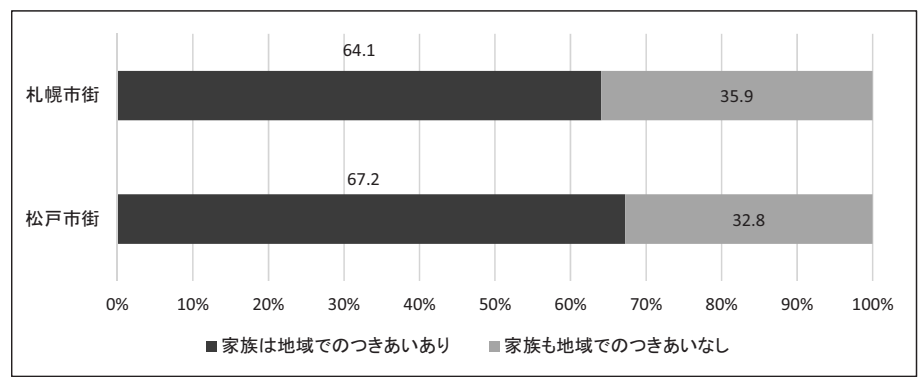

図 6 地域つきあいのない者の同居家族の状況

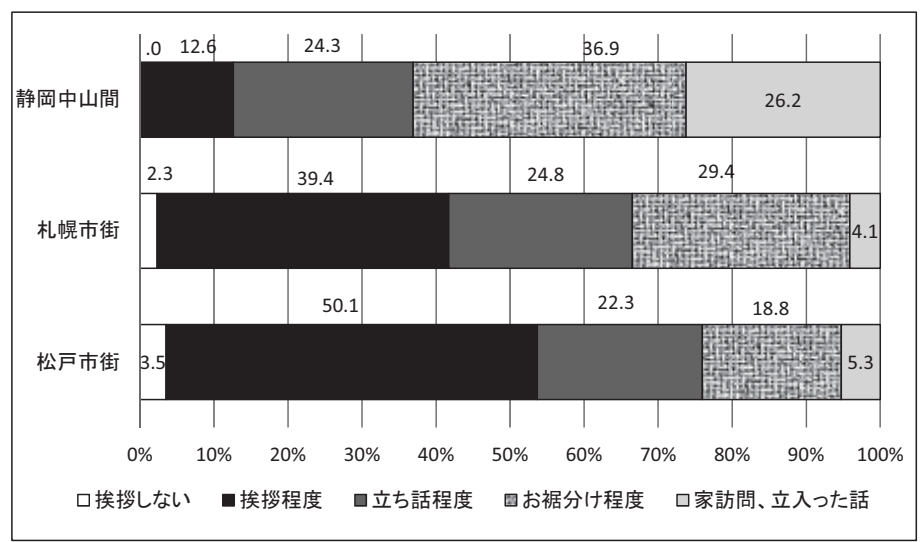

図 7 近所つきあいの内容

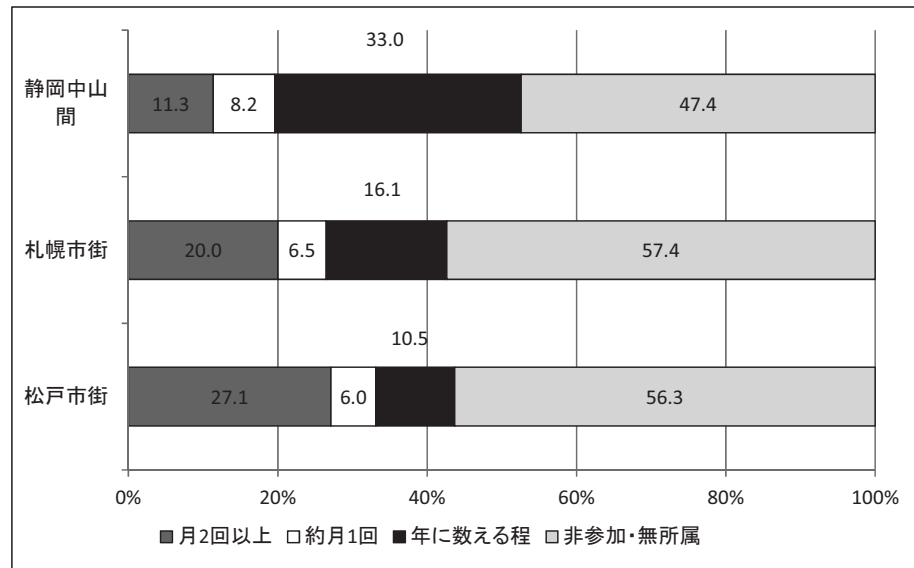

図 8 地域外組織への参加頻度

で過ごす傾向が確認される（図 2)。また、主に「地区内」と回答し た割合を見ると、松戸市街 $4.1 \%$ 、札幌市街 $5.9 \%$ 、静岡中山間で
$43.4 \%$ と、顕著な差異がある。大都市地域では交通の利便性から生 活圈域が地区内に完結しないが、現代的な娛楽施設等が少なく、こ うした施設から遠隔にある中山間地域では、余暇を地区内で過ごす 慣習、行動様式が残存すると考えられる。

\section{4 、交流活動の実態}

\section{$4-1$. 地域内の交流活動}

\section{1）地域組織活動}

地域組織へ「全く参加しない、ほとんど参加しない」と回答する （以下、地域組織一不参加と表記）割合を見ると、松戸市街 $58.6 \%$ 、 札幌市街 $36.0 \%$ 、中山間 $7.8 \%$ である（図 3 ）。首都圈大都市地域で は約 6 割、地方圈大都市地域では約 4 割と約 2 割の差が見られる。 中山間地域であっても、約 1 割が地域組織へ不参加である。

また、定期的、日常的に地域組織活動に参加し、地域組織の活動 の中心的層であると考えられる「約月 1 回」と「月 2 回以上」と回 答する層を併せると、松戸市街 $11.4 \%$ 、札幌市街 $8.4 \%$ 、静岡中山 間 $40.7 \%$ であり、大都市地域で約 1 割であったのに対して、中山間 地域では約 4 割に上る。首都圈大都市地域と中山間地域を比較する と、「地域組織への不参加」より、その差異が少ない。また「地域組 織へ不参加」のうち、「家族も地域組織へ不参加」と回答した者は松 戸市街 $59.6 \%$ 、札幌市街 $60.3 \%$ であり、大都市地域約 6 割である(図 4 )。つまり、松戸市街の $34.9 \%$ 、札幌市街の $21.7 \%$ は、世帯単位 で「地域組織へ不参加」な状態である（静岡中山間は該当サンプル 数が 6 のため割愛)。

\section{2 ）地域での個人的なつきあい}

地域内でのつきあいについて、「全くない、ほとんどない」と回答 する（以下、地域でのつきあいなし）割合が、松戸市街 $63.0 \%$ 、札 幌市街 $52.0 \%$ 、静岡中山間 $9.7 \%$ であり、首都圈大都市地域約 6 割、 地方圏大都市地域約 5 割、中山間地域約 1 割である（図 5)。

また、定期的、日常的に地域でのつきあいを実施し、地域でのつき あいに積極的であると考えられる層である「約月 1 回」と「月 2 回 以上」を併せると、松戸市街 20.7\%、札幌市街 $19.3 \%$ 、静岡中山間 $45.6 \%$ であり、大都市地域で約 2 割、中山間地域で約 5 割である。 つまり、地域組織での不参加層と積極層の比較と同様に、「地域での つきあいなし」より、大都市地域と中山間地域の差異は少ない。

つまり、大都市地域では、中山間地域に比べるとつきあいに消極 的な層の割合が多いが、中山間地域に比べて少ない積極的な層の割 合の差異は、前者ほどではないと言える。

「地域でのつきあいなし」のうち、「家族も地域でのつきあいなし」 との回答が、松戸市街 $32.8 \%$ 、札幌市街 $35.9 \%$ であり、概水各地域 3 割強となる(図 6 )。つまり、松戸市街の $20.7 \%$ 、札幌市街の $18.7 \%$ 、 大都市地域の約 2 割は、世帯単位で地域でのつきあいがない（静岡 中山間は該当サンプル数が 6 のため割愛)。

\section{3 ) 近所つきあい}

近所付き合いについて、「挨拶もしない」もしくは「挨拶ぐらいは する」の割合（以下、挨拶程度）を見ると、松戸市街 $53.6 \%$ 、札幌 市街 $41.7 \%$ 、静岡中山間 $12.6 \%$ で、大都市地域で約 4- 5 割、中山 間地域が約 1 割である（図 7 ）。大都市地域において $3 \%$ 前後では あるが、「挨拶しない」との回答も見られる。

また、近所つきあいに積極的であると考えられる「お裙分け程度」、 


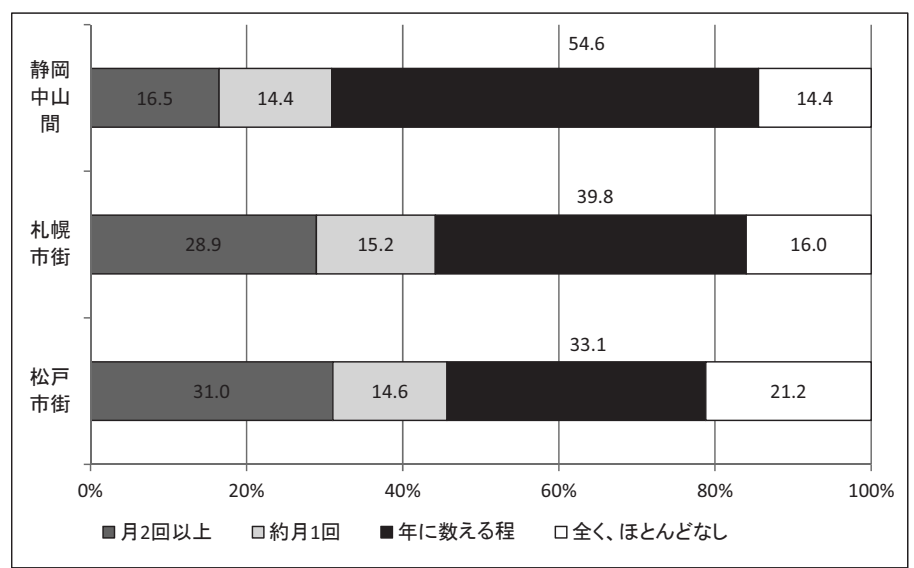

図 9 地域外つきあいの頻度

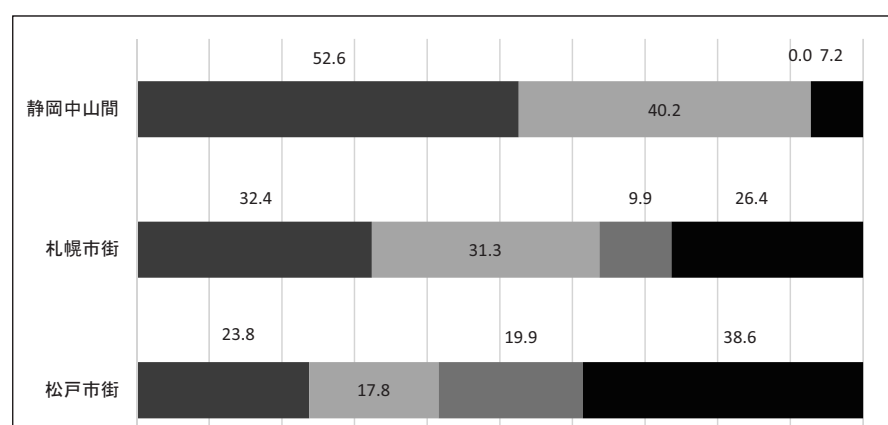

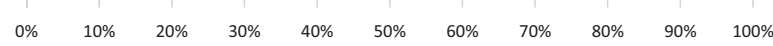

-1地域組織·地域外組織ともに参加四地域組織に参加するが地域外組織に不参加

曰地域組織にこ不参加だが地域外組織へ参加 - 地域組織、地域外組織ともに不参加

図 10 地域組織参加と地域外組織参加の関係

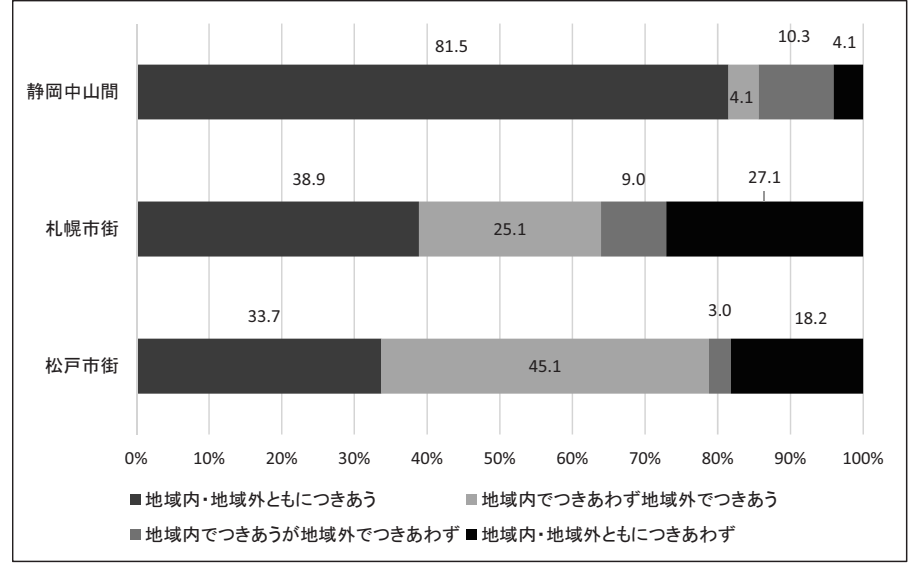

図 11 地域つきあいと地域外つきあいの関係

「家を訪問、立ち入った話をする」を併せた割合は、松戸市街 $24.1 \%$ 、 札幌市街 $33.5 \%$ 、静岡中山間 $63.1 \%$ 、大都市地域で約 3-4 割、中山 間地域で約 6 割であり、「挨拶程度」より大都市地域と中山間地域の 差異は少ない。

\section{4-2. 地域外組織活動、地域外のつきあい}

\section{1 ）地域外組織参加と地域外つきあいの有無}

地域外組織への「非参加、無所属」との回答（以下、地域外組織へ 不参加と表記）の割合を見ると、松戸市街 $56.3 \%$ 、札幌市街 $57.4 \%$ 、 静岡中山間 $47.4 \%$ で、大都市地域で約 6 割であり、中山間地域が約 5 割である (図 8 )。地域組織への不参加と比較すると、松戸市街で
はほとんど変わらず、札幌市街では、地域外組織への不参加が約 2 割多く、静岡中山間では約 4 割多い。首都圈大都市地域では、地域 組織と地域外組織の位置づけに差異はないが、地方圈大都市地域、 中山間地域では、地域組織への参加が優位になることが分かるが、 地域外組織への不参加だけを見ると、地域間差異は少ない。

地域外での個人的つきあいが「全くない、ほとんどない」との回 答（以後、地域外でのつきあいなしと表記）の割合は、松戸市街 $21.2 \%$ 、札幌市街 $16.0 \%$ 、静岡中山間 $14.4 \%$ であり、各地域約 2 割前後である（図 9）。「地域でのつきあいなし」と同様に、首都圈 大都市地域でその割合が高く、中山間地域で割合が少ないが、その 差異は、「地域でのつきあいなし」程ではなく、地域間の差異は少な いと言える。

\section{2 ) 地域外と地域内での交流の関係}

「地域組織に参加し地域外組織に参加しない」層が、松戸市街 $17.8 \%$ 、札幌市街 $31.3 \%$ 、静岡中山間 $40.2 \%$ に対して、「地域外組 織には参加するが地域組織には参加しない」層が、松戸市街 19.9\%、 札幌市街 9.9\%、静岡中山間 $0.0 \%$ である（図 10）。つまり、組織活 動が地域外で完結する層が、首都圈大都市地域で約 2 割、地方圈大 都市地域で約 1 割見られたが、中山間地域では皆無であった。逆に、 地域内で完結する層は、首都圈大都市地域で約 2 割、地方圈大都市 地域で約 3 割、中山間地域で約 4 割であった。

一方、「地域でのつきあいはあるが、地域外のつきあいがない」層 は、松戸市街 $3.0 \%$ 、札幌市街 $9.0 \%$ 、静岡中山間 $10.3 \%$ であり、 「地域でのつきあいがなく、地域外のつきあいがある」層が、松戸 市街 $45.1 \%$ 、札幌市街 $25.1 \%$ 、静岡中山間 $4.1 \%$ である（図 $11 ） 。$ つまり、地域外でつきあいが完結する層が、首都圈大都市地域、地 方圈大都市地域で約 5 割、約 3 割いるが、中山間地域ではほとんど 見られない。また、地域内でつきあいが完結する層は、いずれも約 1 割以下で、中山間地域では、地域内外にわたりつきあう層が多い。

\section{$4-3$. 各指標の年代別分析}

地域組織への不参加率を年齢別に見ると、松戸市街、札幌市街で は年齢が上がると不参加率が減少する（図 12 )。一方、静岡中山間 では、逆に年齢が上がると不参加率が増加寸る。つまり、大都市地 域では年齢が下がるほど、共同体への帰属意識が低いが、中山間地 域では、若年層の地域組織での役割分担が求められ、高齢層の地域 組織から引退が要因である。「地域でのつきあいなし」層を年齢別に 見ると札幌市街、静岡中山間では、カイ 2 乗検定により年齢の有意 差が、統計上得られない。松戸市街では 40 ・50 代の不参加率が若干 高いが、差異がそれほどは見られない。つまり、地域組織への参加 に比べて、年齢による差異はあまり見られない。「近所つきあいが挨 拶程度」層を年齢別にみると、松戸市街、札幌市街ともに、年齢が 高くなるほど、その割合が減少する。静岡中山間はサンプル数が少 ないため、分析は割愛した。

地域内の交流を総じて見ると、松戸市街の地域組織参加、地域の つきあい、近所つきあい、札幌市街の地域組織参加、近所つきあい では、年齢が高くなると交流層が多い傾向にある。若年層の役割分 担が求められ、高齢層の引退が見られる中山間地域では、地域組織 参加において年齢が低くなると交流層が多い傾向にある。 4-4. 非交流層

\section{1) 地域非交流層と社会非交流層}




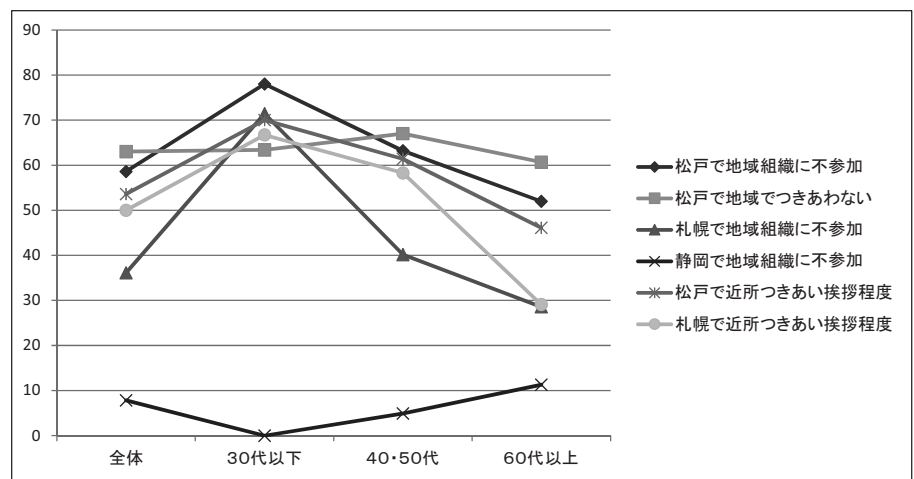

地域組織参加と年代 (松戸) $\times 2=18.8$ (有意率 $1.6 \%$ )、地域組織参加と年代 (札幌) $\chi 2=40.4$ (有意率 $0.1 \%$ 未满)、地域組織参加と年代（静岡） $\chi 2=24.2$ (有意率 $0.2 \%$ )、地域つきあいと年代（松戸） $\times 2=15.4$ (有 意率 $1.7 \%$ )、地域つきあいと年代（札幌） $\chi 2=11.6$ (有意率 $7.3 \%$ で不適）、地域つきあいと年代（静岡） 代（札幌） $\times 2=53.6$ (有意率 $0.1 \%$ 未満)、近所つきあいと年代（静岡） $\chi 2=3.5$ (有意率 $74.2 \%$ で不適）

図 12 年齢別の地域組織不参加、地域つきあい未実施の割合

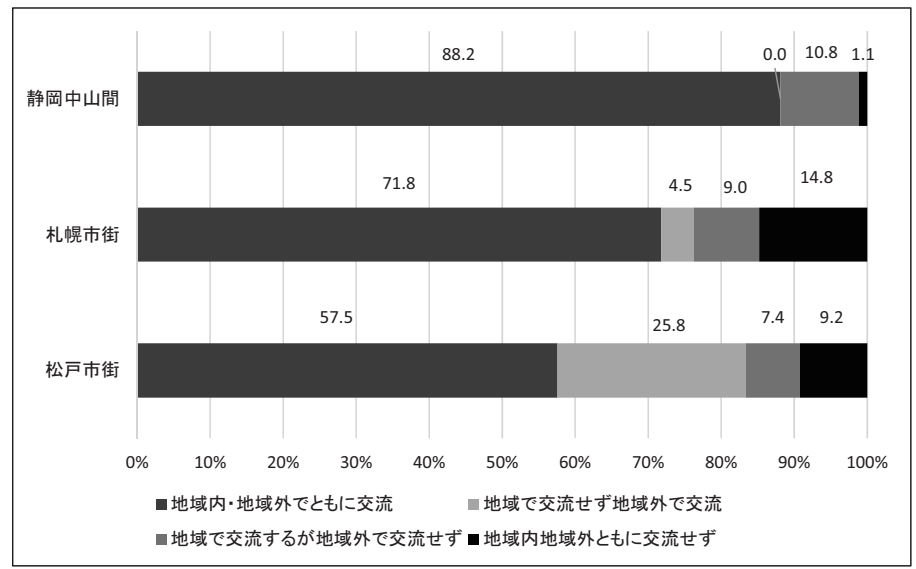

図 13 地域内と地域外での交流および非交流

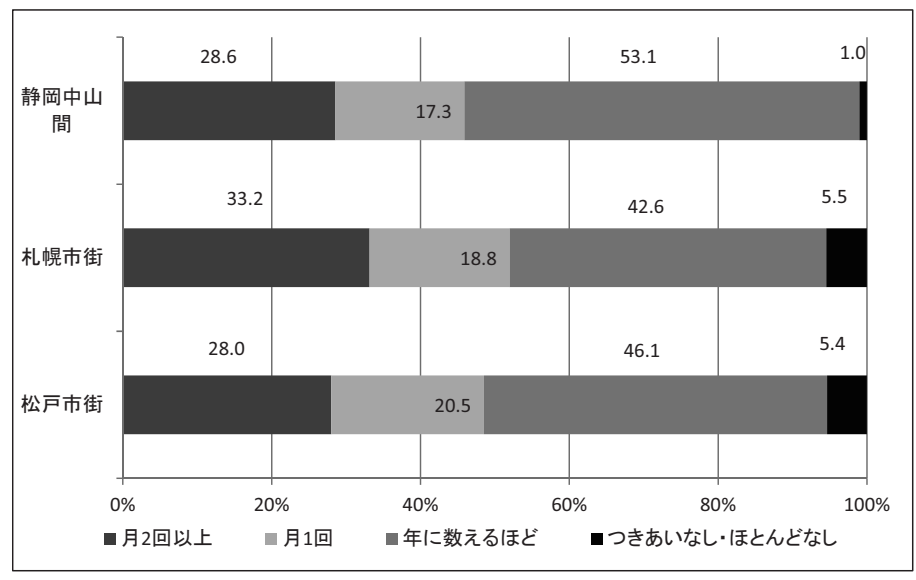

図 14 親戚つきあいについて

まず「地域組織へ不参加」かつ、「地域でのつきあいなし」かつ、 「近所つきあいが挨拶程度」の層注14）を、地域での交流がない「地 域非交流層」注 1 5) とする。その割合を見ると、松戸市街 35.0\%（121 人)、札幌市街 $19.3 \%$ (74人)、静岡中山間 $1.1 \%$ （1 人）である（図 13)。首都圏大都市地域で約 4 割弱、地方圏大都市地域で約 2 割が地 域と関わりを持たずに生活している。

次に、こうした「地域非交流層」のうち、「地域外組織へ不参加」 かつ、「地域外でのつきあいなし」層を、地域内外において交流がな い「社会非交流層」注 15$)$ と寸る。この社会非交流層の割合を見る
と、松戸市街 $9.2 \%(30$ 人)、札幌市街 $14.8 \%$ (17 人)、静岡中山間 $1.1 \%$ (1 人) である。一方、地域非交流層であっても、地域外で交 流する層が松戸市街で $25.8 \%$ 、札幌 $4.5 \%$ 見られ、中山間では見ら れなかった。大都市地域では社会非交流層が約 1 割見られる。同時 に地域とつながりがなくても、地域外での人間関係を生活の基礎と する層が、首都圈大都市地域では約 3 割存在する。地方圈大都市地 域では、地域内外、両方で交流する層が首都圈大都市地域より 1 割 以上多いものの、社会非交流層は若干多く、地域外で交流が完結す る層も少なく、地域外の居場所（サークル、習い事など）のバリエ ーションやこれらを利用する行動が首都圈大都市地域に比べて少な いことが推察される。

\section{2）その他の非交流}

別居家族・親戚、相談相手といった上記とは異なる相手との交流 活動を見る。別居家族・親戚と「つきあいがない、ほとんどない は松戸市街で $5.4 \%$ 、札幌市街で $5.5 \%$ 、静岡中山間で $1.0 \%$ である。 大都市地域で約 $5 \%$ が、別居家族・親戚との交流がない（図 14）。 一方、「深刻な悩みを相談する相手」の有無を聞いたところ、「相談 相手がいない」は松戸市街で $30.7 \%$ 、札幌市街で $33.2 \%$ 、静岡中山 間で $15.6 \%$ である。大都市地域では約 3 割で相談相手がいないと回 答している(図 15)。

\section{3 ) 非交流層の属性}

各地域の年齢構成と、それぞれの「地域非交流層」、「社会非交流 層」の年齢構成を比較してみる（図 16）。

地域非交流層では松戸市街、札幌市街、社会非交流層では、札幌 市街において、全体の割合に比べると地域非交流層では「60 代以上」 の割合が減少する傾向が見られる。しかし、総じて、地域非交流層、 社会非交流層は全体に比べこうした若干の偏りが見られる部分もあ るが、こうした層は各年代に存在するとも言える。

\section{5.おわりに}

本編で得られた首都圈および地方圈大都市地域（既成市街地）、中 山間地域の知見をまとめ、前編9１１0）で得られた首都圈の小都市地 域（中心市街地）および近郊農村地域（近郊地域と表記）と合わせ て考察する。本研究は、調查対象地が少なく、有効回答率を見込ん で調查対象地を選定するなど事例研究としての限界性があり、全国 的な傾向を示寸わけではないが、これを踏まえつつ、地域非交流層、 社会非交流層の存在を地域毎に定量的、実証的に示すなど、潜在的 課題を現象として確認する事例研究としての有用性を持つと考える。 以下、一般的地域名を挙げるが限られたサンプルからの推察である。 (1)「余睱を主に誰と過ごすか」では、地域に関わらず、仲間や友 人と余暇を主に過ごす生活スタイルは少数派（約 2-3 割）となって いるが、「余暇活動の主たる場所」について、「家で過ごす」インド ア派が都市地域、近郊地域で約 5-6 割であるが、中山間地域では約 3 割に留まり、余暇を家で過ごす傾向は中山間地域でのみ低い。 (2)地域での交流活動を行わない層の割合は、地域組織、地域での個 人的つきあい、近所つきあいのそれぞれで、大都市地域、小都市地 域、近郊地域新住民で約 4-6 割、近郊地域旧住民で約 2-3 割、中山 間地域では約 1 割である。中山間地域では地域での各交流活動を行 わない層は例外的であるが、近郊地域旧住民では都市地域ほででは ないが、一定程度観察される。 


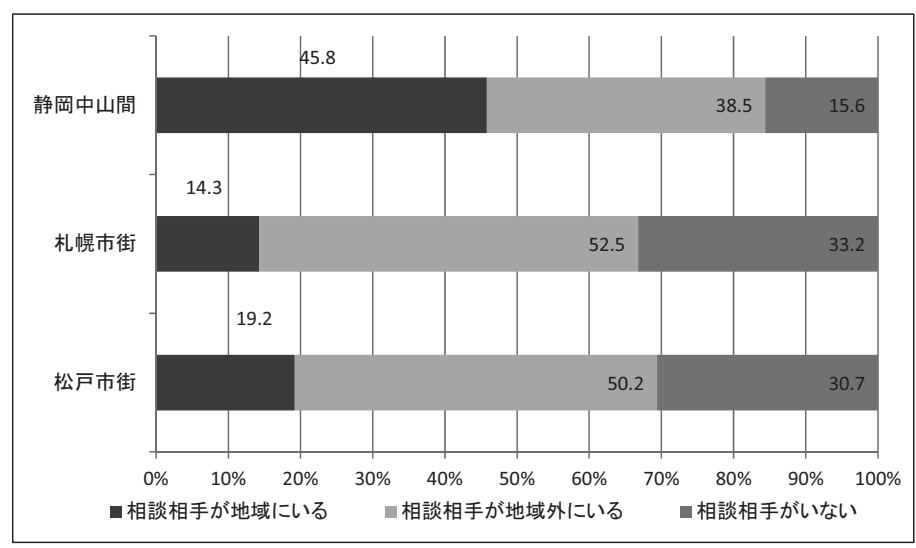

図 15 相談相手について

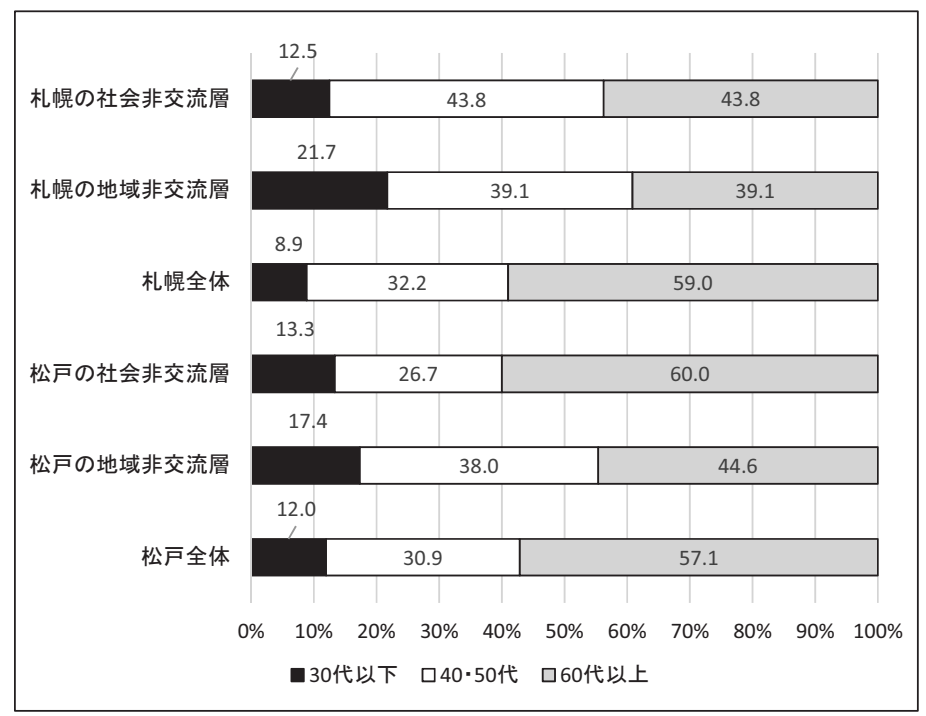

図 16 非交流層と年齢構成

(3)年齢別に地域内交流の不参加状沉をみると、概禅都市地域、近郊 地域で、高齢層の不参加が少ない傾向が見られるが、中山間地域の 地域組織では、地域内で若年層の参加が強く求められており、若年 層の不参加が最も少ない。

(4)地域外でつきあいが完結する層について、首都圈大都市地域約 5 割、小都市地域約 4 割、地方圈大都市地域および近郊地域新住民約 3 割、近郊地域旧住民約 1 割、中山間地域約 $5 \%$ 以下と段階的に分 布する。つまり、近郊地域、中山間地域を除けば、各地域で約 3-5 割の層が地域外でつきあいが完結している。

(5)地域非交流層について、首都圈大都市地域が約 4 割、地方圈大都 市地域、小都市地域と近郊地域新住民は概衩約 2 割前後であり、近 郊地域旧住民、中山間地域が約 $6 \%$ 、約 $1 \%$ と低い。社会非交流層 について、大都市地域、小都市地域および近郊地域新住民では約 1 割前後に上るが、近郊地域旧住民 $3 \%$ 、中山間地域約 $1 \%$ である。 地域において家族以外の者と交流が見られない層は、近郊地域旧住 民、中山間地域では例外的に見られる程度である。一方、都市地域 および近郊地域新住民では約 $2-4$ 割に上り、地域内だけでなく地域 外を含めて家族以外の者と交流が見られない層も約 1 割に上ること が分かる。また、こうした層の属性的特徴は、年齢で見ると、若干 の偏りはあるが、様々な年代に見られ、特定の年齢層に起きている 現象ではない。
(6)同居家族を含めた地域内非交流層は、首都圈大都市地域で約 1 割、 別居家族・親戚との非交流は大都市地域で約 $6 \%$ 程度である。相談 相手がいない層は大都市地域で約 3 割であり、大都市地域では、世 帯単位での地域内非交流、血縁者との非交流、相談相手がいないと いう意味で、加齢による交際範囲の縮小などにより、「広義の孤立」 からより深刻な「狭義の孤立」(社会的孤立)」一変移寸る可能性の ある層の存在が確認できた。

最後に地域間の差異についてまとめる。地域内外の非交流に関わ る各指標を個別に比較し総合的に見ると、生活様式や情報という点 では都市部、農村部を問わず地域の均質化が言われているが、大都 市地域と中山間地域の差異は顕著で、中山間地域の共同体的連帯は 健在である。一方、都市近郊地域では旧住民を含め、中山間地域と 都市地域の中間的值を示す。また首都圏大都市地域の方が地方圈大 都市地域より地域内外での非交流が目立つ（さらに前編と合わせて 見ると、首都圈小都市の中心市街地、近郊農村地域新住民の方が、 地方圈大都市地域よりつきあいの希薄化の進行が有意に見られる部 分もあった)。つまり、地域内外の非交流は、人口規模（大都市、小 都市、都市近郊など）だけでなく、首都圈が地方圈かの差異による 影響も見られると推察される。

農村地域特有のコミュニケーション上の課題は、(1)農家と非農家、 新住民と旧住民などの階層毎に価值観や生活時間、生活スタイルに 顕著な差異があることよる相互理解や交流の阻害、(2)大都市地域に おいては多様に見られる趣味のサークルや習い事、NP0 等市民団体 のように、活動内容や仲間を個人の意志で選ぶことができる地縁組 織以外の選択肢（オープンな居場所）が限られていることなどであ る。近年、農村地域でのいわゆる「引きこもり」層の一定程度の存 在が報告されているが、上記課題もこの存在の一要因であると推察 される。従って、農村地域、特に都市近郊農村地域における地域内 外の非交流という現象の存在を問題提起寸ること、同時にこれら課 題の解消に資する活動を支援することが提言できる。

今後の研究課題として(1)各地域のインタビュー調査を行い、本研究 で定量的に示した地域間差異の質的意味を明らかにし、(2)単身高齢 者、貧困層等、より社会的孤立が懸念される階層に対象を絞り、居 場所づくりの条件を整理し、(3)本研究は男性が対象であったが、女 性を含めた調査性差を分析することを挙げる。

\section{謝辞}

調查に協力頂いた調查対象地域の関係自治体ご担当者、地区代表 者、住民の皆様に感謝を捧げる。本編は文部省科学研究費補助金基 盤研究Cによる。

\section{参考文献}

1）東京の高齢者世帯、 $44 \%$ が一人暮らし 20 年後、日本経済新聞 2014 年 4 月 12 日電子版

http://www. nikkei.com/article/DGXNASFS1103W_R10C14A4EE8000/ (2015.1. 9 最終閲覧)

2）孤立死防げ 自治体動く,朝日新聞 2012 年 3 月 10 日朝刊、2012

3） NHK 無縁社会取材班：無縁社会一無縁死 3 万 2 千人の衝撃一、文芸春 秋, 2010

4）橘木俊詔：無縁社会の正体、PHP 出版, 2011

5）島田裕巳：人はひとりで死ぬ、NHK 出版, 2011

6) 藤原智美：暴走老人、文藝春秋, 2009

7）広井良典：コミュニティを問い直す、筑摩書房、2009

8）姜尚中：悩む力、集英社新書, 2008 
9）齋藤雪彦 : 都市近郊地域における余暇生活とその個人化、孤立に関する 研究, 日本建築学会計画系論文集 673、pp. 543-552,2012.3

10) 齋藤雪彦: 首都圈小都市の近郊農村地域と中心市街地における余暇および 交流活動に関する研究、日本建築学会計画系論文集 683、pp73-80、2013.1

11）余田博通：農村社会学、川島書店, 1969

12) 蓮見音彦 : 社会学講座第 4 巻 農村社会学、東京大学出版会, 1973

13）齋藤雅茂ほか 3 名：大都市高齢者の社会的孤立の発現率と基本的特徵、 社会福祉学 50(1)、pp. 110-122, 2009

14）河合克義：大都市のひとり暮らし高齢者と社会的孤立、社会学福祉学、 51 (2) 、pp. 150-152, 2010

15)猪岡まり子ほか 4 名: 地域行事・地域活動への青少年の参加と地域組織側 の認識・動向の関連に関寸る研究、日本建築学会大会学術講演梗概集、 F-1, pp. 607-608, 1999

16) 多田玲於奈、大垣直明 : 地方都市における住民の役割意識と地域活動に関 する研究、日本建築学会大会学術講演梗概集, E-2, pp. 661-662, 2001

17) 高村亮、後藤春彦ほか: 郊外住宅地における居住者の地域活動参加の実態、 日本建築学会大会学術講演梗概集、F-1,pp. 1089-1090, 2007

18) 花原裕美子ほか 2 名: 地域活動を支える個人・組織のつながりの形成要因、 日本建築学会大会学術講演梗概集 E-1, pp. 1259-1260, 2009

19）芝池綾、谷口守、松中亮治 : 意識調査に基づくソーシャルキャピタル形 成の構造分析、日本都市計画学会都市計画論文集 42-3、pp. 343-348, 2007

20）内閣府経済社会総合研究所：コミュニティ機能再生とソーシャル・キャ ピタルに関する研究調査報告書、内閣府国民生活局市民活動促進課、2005

21) 藍沢宏、鈴木麻衣子、斉尾直子 : 住民の地域社会活動の形成とその展開方 法に関する研究、日本建築学会計画系論文集 533、pp. 89-95, 2000.7

22) 菅原麻衣子、藍沢宏、篠塚麻衣 : 高齢化の進む中山間地域における地域社 会の範域形成、日本建築学会計画系論文集 606、pp. 85-92,2006.8

23) 和田正人：インターネット利用と自己愛人格, 東京学芸大学紀要 59 , pp. 535-541, 2008

24）宾戸邦章 : 高齢期における幸福感規定要因の男女差について, 日本版 Gen eral Social Surveys 研究論文集 6,pp45-56,2005

25) 桜井康宏 : 生活時間と階層的視点からみた余暇性向とグループ活動参加の 動向、日本建築学会計画系論文報告集 349、pp. 32-41, 1985. 3

\section{注}

注 1 ）文献 1)

注 2 ) 例えば、文献 2) などでは、2012 年 1-3 月だけで、数件の孤立死が取 り挙げられており、貧困による餓死と、介護者、被介護者世帯での、 介護者の病死等が被介護者の孤立死につながる問題が指摘される。 文献 3) では「つながりのない社会、縁のない社会」を無縁社会と呼 称し、特に孤独死した上で、さらに引き取り手のない死を無縁死と定 義し、その数を行政への聞き取り調査から全国で年間 3 万 2 千人と見 積もっている。文献 4) では主に、無縁社会の背景である高齢者、主 婦層、若者層など各階層の孤立の実態を明らかにしている。また、文 献 5）では、近代化以前の封建的社会から今日に至る経緯を説き起こ し無縁社会の到来は、個人の自由とのトレードオフの関係にあり、必 然であるとしている。また、これらの文献では、家族との疎遠、家族 以外の者との疎遠が論点となっているが、本編では、地域社会の問題 をテーマとするため、家族以外の者との疎遠に焦点を絞り論を進めた。

注 3）福祉学の分野等では主に「狭義の孤立」を課題とするが、本編では 地域社会の変容、個人の余暇・交流活動の実態を捉えるため、「広義 の孤立」を主たる課題として設定した。

注 4）例えば文献 6）によれば、高需者が感情を爆発させる事例が多発して いるが、これは年功序列に代表される伝統的価值観で若い時に年配者 に敬意を払ってきたが、価值観の変化で自身が高齢者になった時には、 周囲から敬意を払われない状況によると指摘している。例えば、文献 7）では諸外国と比較し、都市における見知らぬ者同士のコミュニケ ーションのぎこちなさ、不全を指摘している。

注 5）例えば、文献 8）では、こうした市場経済と科学技術の発達による自 由と個人化が、必然的に個人の孤独（孤立）を生み出すとしている。

注 6 ）例えば、文献 4 ） では、勤労者と企業の関係の変化を指摘している。

注 7）文献 9） 10)
注 8）自治会活動を見ると、U 地区では、概ね草刚りやお祭りなど伝統行事と 常会 (月 1 回程度) 行っているが、M 地区では、お祭り・イベント（公 園祭り、盆踊り）、防災訓練、公園清掃を行っている自治会、 $K$ 地区 では、お祭り・イベント（焼肉、盆踊り、夏祭り）、公園清掃を行っ ている自治会などが見られるが、年 1 回の総会と年数回の役員会以外 に常会のようなものはない。U 地区に見られる各自治会単位の婦人会、 老人会、子供会、消防団については、M 地区では老人会のみ見られ、K 地区では、連合自治会単位での婦人会、老人会のみが見られる。その 他の組織としてU 地区が生産グループ組織、檀家組織、講が見られる が、M 地区では見られず、K 地区では、体育振興組織、福祉活動組織が 見られる。中山間では、地域組織の種類や活動内容は伝統行事や伝統 的な組織が多く、活動頻度が高いが、大都市地域では、伝統的な組織 が少なく、活動頻度も低いものの、公園祭りや体育振興組織など伝統 的ではない新しい取り組みや組織が見られる。加入率についても、U 地区が 100\%に近く、K地区も 9 割を越えている自治会がほとんどだが、 M 地区では 6 割前後の自治会が多い。

注 9 ）例えば文献 24）では、目的合理的志向性、手段的関係志向が男性の社 会関係資本の少なさにつながっているとしている。

注 10）「地域」とはアンケートを行った自治会連合会を範囲とする地域とす る。地域組織、地域外組織をアンケートでは地縁的組織、学校・行政 的組織、自主的・任意的組織、商業的組織、仕事関係組織と分類し例 示している。また地域内のつきあい、地域外のつきあいを会話、食事、 飲み会、旅行、釣り、ゴルフなどと例示し、一定の親密な関係を前提 とする行為について聞いている。ここで、「地域のつきあい」とは、 つきあう相手が地域に居住することを指し、交流活動の場所を指すも のではない。

注 11）ここでは、まず家族や個人だけで過ごし、家族以外の他者と関わ りが少なくなる現象を捉えるため、まず、家族以外の者と主に過ごす 「集団型」、家族以外の者とも、家族、個人とも過ごす「混合型」を設 定した。次に、家族や個人で過ごす者のうち、家族ともあまり過ご さず、主に個人で過ごす「個人型」、これ以外のタイプを「家族型」 とした。また、上記以外で、余㗇活動と非余暇活動の境界があいま いであるか、仕事・農業ばかりのタイプとして「仕事・農業型」を 設定した。具体的には、ヒアリング記録から、中山間では、庭仕事、 家庭菜園、釣り、自然鑑賞など自然環境を生かした、大都市では、 家の中でのゲームやテレビ鑑賞などの屋内での個人的活動が多く、 中山間では、伝統行事など義務的な、大都市地域ではスポーツ・習 い事・福祉活動など、自主的な集団活動が多く見られた。

注 12）例えば、文献 25）によれば、地方都市である豊田市、大野市の市街地 の余暇調査（1978 年、1974 年実施）では、主な余暇の過ごす相手 が「一人」と「家族」の合計は各 $49 \%$ 、53\%であり、30 年程前に比 べても、地域は違うものの、本研究の市街地住民より 2 割余り割合 が少なく、余暇の個人化が進行していることが推察できる。

注 13）この要因としてヒアリング記録から、専業農家、兼業農家、非農 家では、農作業時間、通勤時間、余暇時間などの生活サイクルが 合わず、このことより、義務的、自主的なつきあいの場が減少 したことが挙げられる。また同時に就業環境の違い等から共通の 話題、価值観を持てないという声も聞かれた。

注 14）ここで近所つきあいが「挨拶程度」か「挨拶もしない」層を地域非交 流層の条件とした理由は、地域組織に属さず、地域のつきあいがなく ても、挨拶程度を超える近所づきあいがあれば、地域で一定の定常的 な人間関係を営んでいるため、こうした層を地域非交流層から除外寸 るためである。

注 15 )「地域組織へ不参加」かつ、「地域でのつきあいなし」かつ、「近所つ きあいが挨拶程度（挨拶もしないを含む）」と回答した層を、地域に おける交流が見られない層として、「地域非交流層」とする。

また、「地域非交流層」のうち、「地域外組織へ不参加」かつ、「地 域外でのつきあいなし」と回答した層を、地域内外において交流が ない、つまり家族や親戚以外の仲間や友人と交流がない層として、 「社会非交流層」とする。 


\title{
A COMPARTIVE STUDY ON THE RECREATION, ASSOCIATION LIFE, IN URBAN DISTRICTS OF LARGE CITIES AND IN THE INTERMEDIATE AND MOUNTAINOUS AREA
}

\author{
Yukihiko SAITO* and Akio SHIINO** \\ * Assoc. Prof., Graduate School of Horticulture, Chiba University, Dr.Eng. \\ ** Prof., Faculty of Engineering, Hokkaido University of Science, Dr.Eng.
}

This paper aim to clarify the situation of the isolation in urban districts of large city and a district of intermediate and mountainous area among residents in the view point of recreational life. Modern consuming life such as an internet life and delivery services, convenience shop spreading, the change of traditional way of thinking as a hierarchy social system breaking, as democratic social system spreading, and the labor circumstances changing to severe under globalization, are backgrounds of isolation. We want to compare the situation of isolation and of social bonds breaking through case studies.We send questionnaire survey at the Miyako-dai district in Matsudo city, Chiba prefecture, at the Kanayama district in Sapporo city, Hokaido prefecture and at the Umegashima district in Sizuoka city, Sizuoka prefecuture. Miyako-dai district is selected as a urban district of large city in metropolitan area. Kanayama district is selected as a urban district of large city in province area. Umegashima is selected as a village district in an intermediate and mountainous area. 343 questionnaire sheets are recollected at the Miyako- dai district(1795 families live, recollecting rate is 19.1\%). 397 are recollected at the Kanayama district(1415 families live, recollecting rate is $28.0 \%$ ). 103 are recollected at the Umegashima district ( 172 families live, recollecting rate is $59.9 \%$ ).

We have to pay attention that under limitation of case study, this study does not point out the whole situation of Japan. Analyzing the whole situation of Japan is the next study subject to do.

It makes clear as follows.

1) About from $40 \%$ to $60 \%$ residents do not join each local association activities while about $10 \%$ resident do in intermediate and mountainous area .

2) About from $20 \%$ to $35 \%$ resident do not join almost all of local association activities and about $10 \%$ resident do not join almost all of association activities.

3) About 40\% residents in urban district of large city in metropolitan area and about $20 \%$ in an urban district of large city of province area are isolated in their regional society.

4) About $10 \%$ residents in urban district are isolated in whole society except relatives.

5) Such isolation groups of residents are seen in every ages which is not seen in a specific age.

6) In general, at viewpoints of the way of thinking, life style, and information, village societies are said to have become urbanized. But the village society of the case study seem to have maintained social bonds which have passed from ancient times.

7) Including previous studies, isolation are serious in urban district, while it is not serious in intermediate and mountainous area. But the tendency of suburban village district is middle of urban district and village district in intermediate and mountainous area.

(2015 年 11 月 2 日原稿受理, 2016 年 2 月 12 日採用決定) 